\title{
The Sense of Space and Arctic Nature in Cora Sandel's Kranes konditori: interiør med figurer (Krane's Café: An Interior with Figures)
}

\section{Raluca-Daniela Răduț}

Babeș-Bolyai University, Cluj-Napoca, E-mail: raluca_daniela_radut (at) yahoo.com

\begin{abstract}
The paper combines the close reading technique of the novel Kranes konditori: Interiør med figurer (Krane's Café: An Interior with Figures, 1946), written by the classic Norwegian writer Cora Sandel (1880-1974) with a spatial approach which aims to present the past and the present of the novel's main character, Katinka Stordal. The action takes place in a small town situated in northern Norway, at Krane's Café. It is worth noting how topography, the seasons of the year, the Arctic climate and nature are gradually reflected in the novel. On the one hand, the novel is placed at the crossroads of a spatial perspective and the literary criticism, which has in its centre Krane's Café, the place where almost all the characters are brought together and which is the most suggestive and representative interior space of the novel. On the other hand, the subtitle An Interior with Figures strengthens the idea of a mixture of literary genres which includes elements from novel and drama. Moreover, it resembles the title of a work of art, for instance, a painting where all the characters are simply figures animated by the beauty of the Arctic scenery.
\end{abstract}

Rezumat

Lucrarea de față combină tehnica close reading-ului aplicată pe romanul Kranes konditori: Interiør med figurer (Cafeneaua lui Krane: Interior cu Portrete, 1946), al Corei Sandel (1880-1974), scriitoare clasică norvegiană, си o abordare topografică, ambele având ca scop prezentarea faptelor din trecutul și prezentul personajului principal, Katinka Stordal. Acțiunea are loc într-un oraș mic situat în nordul Norvegiei, la Cafeneaua lui Krane. De remarcat este modul în care topografia, anotimpurile, climatul arctic și natura se reflectă treptat în roman. Pe de o parte, romanul este plasat la intersecția dintre dimensiunea spațială și cea a criticii literare, având ca punct de reper Cafeneaua lui Krane, locul unde majoritatea personajelor se întâlnesc, fiind cel mai sugestiv și reprezentatio interior al romanului. Pe de altă parte, subtitlul, Interiør med figurer (Interior cu Portrete) pune in lumină o combinație de genuri literare, care include elemente din roman și dramă. În plus, titlul este asemănător cu cel al unei opere de artă, de pildă o pictură, în care toate personajele apar ca portrete însuflețite de frumusețea peisajului arctic.

Keywords: the sense of place; Arctic nature and climate; Cora Sandel; Kranes Konditori: Interiør med figurer (Krane's Café: An Interior with Figures); close reading technique; spatial approach

CC BY-SA License (https://creativecommons.org/licenses/by-sa/2.0)

This paper has been presented at the Eleventh International Conference on Baltic and Nordic Studies in Romania: ReThinking Europe in Scandinavia and the Baltic Sea region, hosted by the Romanian Association for Baltic and Nordic Studies, May 28-29, 2020. 


\section{Introductory remarks}

Cora Sandel (1880-1974) was the pseudonym of the Norwegian writer Sara Fabricius, who was born in Oslo, Norway. According to Professor Per Thomas Andersen, "Sandel wrote impressionistic pictures. She created a literary chromatic palette which is not to be found at any other Norwegian writer. She discovered completely new values of the Norwegian language". ${ }^{1}$ Together with the Norwegian literary figures: Knut Hamsun (1859-1952), Sigrid Undset (1882-1949), Kristofer Uppdal (1878-1961), Rolf Jacobsen (1907-1994), Olaf Bull (1883-1933) and many others, Cora Sandel was a prominent writer of the Norwegian literature between the two World Wars. At the age of 12 she moved together with her family to northern Norway. "In 1892 the family moved to the far north, to Tromsø and had a very different lifestyle. Tromsø was a small town in 1890, with only 7,000 inhabitants; it was in the Arctic Circle, with two months' darkness each year and no electric lights". ${ }^{2}$ She lived in Storgata, the Main Street in Tromsø, in a house which was later turned into a museum, namely Perspektivet Museum (The Perspective Museum), where different exhibitions are organized, including the one about Cora Sandel's life and literary work. The city of Tromsø with its beautiful Arctic and wild nature represented an endless source of inspiration for her writings. In 1906, when she was 25 years old, she moved to Paris to study painting. In 1913 she got married with the Swedish sculptor Anders Jönsson and together they had a son, Erik Jönsson. In 1921 they all moved from Paris to Sweden, where she died in Uppsala, in April 1974.

Even if she did not write biographical novels, the plots of her stories include aspects of her life and educational interests. For instance, in her real life she wanted to become a famous painter, but she did not succeed in this direction. Even if she chose to prioritize her family and the raising of her child, being focused on financial issues, especially after her divorce in 1926,

\footnotetext{
${ }^{1}$ My own translation, original text in Norwegian: "Sandel skrev impresjonistiske bilder. Hun skapte en litterær koloratur som ikke fins hos noen annen norsk dikter. Hun fant helt nye valører i det norske språket"; Per Thomas Andersen, Norsk litteraturhistorie, (The History of Norwegian Literature) (Oslo: Universitetsforlaget, 2012), 385.

2 Janet Garton, Norwegian Women's Writing 1850-1990 (London: The University Press, Cambridge, 1993), 129.
} 
she did not leave her writings undone. All these problems and intellectual preoccupations are reflected in her writings through the female protagonists' life experience.

In 1922 she made her literary debut with the short story Rosina first published in the Norwegian newspaper Arbeiderbladet. In 1926 when she was 46, Cora Sandel published the first novel entitled Alberte og Jakob (Alberta and $J a c o b)^{3}$ from the trilogy about Alberta, followed by Alberte og Friheten (Alberta and Freedom, 1931) and Bare Alberte (Alberta Alone, 1939), which represented a breakthrough in her literary career:

The 'Alberte' trilogy is a study of the artist as outsider. It depicts the slow and painful maturing of a girl who from the start, like the protagonist of 'Happiness', knows only what she does not want to be: what her whole society tries to make her. The trilogy opens in 1903 when she is around sixteen or seventeen, and ends in 1920 when she is around her mid-thirties, [...]. It is more a study of inner development; attention is focused on the periods in which her awareness of her own potential is maturing, or the pressures of existence become so intense that they cause a violent reaction. ${ }^{4}$

The place where this action was set resembles a small town in northern Norway which has the features of a coastal town. The city of Tromsø is evoked only in the first novel, Alberte og Jakob (Alberta and Jacob), the setting in the following two novels from this trilogy being Paris, all the three novels having the characteristics of a bildungsroman, where Alberta, the protagonist, struggled a lot and made enormous efforts in order to achieve her goals in life: "[...] Alberte goes her own way. Despite her lack of articulateness, she is ultimately one of the strongest female figures in Scandinavian literature. The trilogy ends as it began, in coldness and isolation, but Alberte has made the life-threatening element her own". ${ }^{5}$

\footnotetext{
3 The titles of these three volumes were translated by Professor Janet Garton in her book entitled Norwegian Women's Writing 1850-1990. London: The University Press, Cambridge, 1993.

${ }^{4}$ Garton 1993: 133.

${ }^{5}$ Ibid. 137.
} 
According to Barbara Sjoholm, the female protagonist of this trilogy, Alberta Selmer was able to face all the difficulties, without forgetting that one of the most essential things in life is to follow her own dreams and believe especially in her artistic abilities: “Opposed by her family and her society, unsupported by her egotistical artist husband and thwarted by an unplanned pregnancy and motherhood, Sandel's Alberta Selmer nevertheless is - [...] - triumphant by the end of the last book". ${ }^{6}$ This trilogy is a lesson of life in which the determination of the protagonist and her struggle in order to face all the endeavors, in the end turned out to be a great achievement for her career as an artist, at least in fiction if it did not come true in real life: "it's not a story about success, however, as much as a lyrical, often poignant narrative about freedom and identity, a portrait of losing and finding one's voice, over and over again". ${ }^{7}$

On the one hand, even if Cora Sandel spent a significant part of her life in Sweden, she always carried the image of her beloved Tromsø both in her heart and in her writings, Sweden and the surrounding landscapes being totally absent from her novels: "[...] place is where he [the writer] has his roots, place is where he stands; in his experience out of which he writes, it provides the base of reference; in his work, the point of view. [...]. Feelings are bound up in place, and in art, from time to time, place undoubtedly works upon genius". ${ }^{8}$ On the other hand, when showing the presence of the Arctic scenery in Cora Sandel's Alberte og Jakob (Alberta and Jacob), Professor Henning Howlid Wærp from the Arctic University of Norway in Tromsø makes reference in his book Artisk litteratur - fra Fridtjof Nansen til Anne B. Ragde (Arctic Literature - from Fridtjof Nansen to Anne B. Ragde, 2017) to the American researcher Linda Hunt, who associates the place presented in this first novel with 'a Norwegian Arctic town'. ${ }^{9}$

\footnotetext{
${ }^{6}$ Barbara Sjoholm, "Incognito Street", in The American Scholar, vol. 72, no. 3, 2003, 66.

${ }^{7}$ Ibid.

${ }^{8}$ Eudora Welty, "Place in Fiction", in The Eye of the Story. Selected Essays and Reviews (New York: Random House, 1977), 117, 123.

${ }^{9}$ Henning Howlid Wærp. 'Bilder av nord i Cora Sandels forfatterskap' ('Images of the North in Cora Sandel's Literary Work'), in Arktisk litteratur - fra Fridtjof Nansen til Anne B. Ragde (Arctic Literature - From Fridtjof Nansen to Anne B. Ragde), (Stamsund: Orkana Akademisk, 2017), 328.
} 


\title{
Kranes konditori: Interior med figurer (Krane's Café: An Interior with Figures)
}

The novel Kranes konditori: Interior med figurer (Krane's Café: An Interior with Figures) was published in 1946, after the Second World War and it is perceived by many literary critics as a mixture of two literary genres, a novel and a drama. In this sense, the title of the novel is highly suggestive. The first half is suitable for a novel, while the second part seems to be an extra detail, a scenographic element, which gives the impression that Krane's Café is a theatrical scene, the leading actors being the dressmaker Katinka Stordal and the Swedish seaman, Bowler Hat ${ }^{10}$.

\begin{abstract}
Katinka Stordal is a divorced mother of two who makes her living as a dressmaker. Despite being extremely talented, she is still like the seamstresses of older days, overworked and underpaid; an important party is approaching, and she is under pressure from all the ladies of the town to finish their dresses. Exhausted, she comes into Krane's Café in the middle of the morning to relax over a drink. That is bad enough, but when she refuses to return to work and then later is joined by Stivhatten [Bowler Hat], a not very respectable Swedish individual, scandal is in the air. Katinka refuses the efforts of well-meaning friends and family to persuade her to return to her sewing and goes off with Stivhatten to spend the night at his place. He suggests that she should leave town with him, and she is tempting seeing nothing around her but people who want to exploit her for their own ends. Yet she decides in the end to stay because of her teenage daughter. ${ }^{11}$
\end{abstract}

The action takes place during two days in a coastal town from northern Norway. Unlike the other novels, the plot is built almost entirely inside, at Krane's Café, only a few scenes being projected outside. However, the café has its own 'transparency', designed with two large windows which can easily and indirectly communicate with the exterior world, including the Arctic scenery which is depicted as if the reader is contemplating a work of

\footnotetext{
${ }^{10}$ Stivhatten is the Norwegian nickname which is translated into English as Bowler Hat by Elisabeth Rokkan in her English translation of the novel published at Ohio University Press, in 1968. In this article I use the nickname in English.

${ }^{11}$ Garton 1993: 144.
} 
art, a still-life painting, where the only vivid elements are the characters and their life experiences:

Lighter too, since Bleken the master-builder, suggested knocking out two large windows in the wall facing the quay. Before that you could only look out on the High Street, and it was quite dark at the back of the premises. Now the sun streams in, you have a view of the mountains on the other side of the fjord, and on the days when the coastal steamer comes in you can watch it arriving and all the passengers going ashore. Not to mention the cruise ship in summer and the other boats that come in - the local steamers, the Hamburg line. Splendid idea of Bleken's. ${ }^{12}$

The novel begins with the ironic tone of the narrator, who seems to introduce the reader into the world of a small town's gossips and rumors: "There's a lot to be heard before your ears drop off. A true saying as they all discovered at Krane's Café during those two days. [...]. We thought we knew about most things in a small town like this. What we didn't know, we could work out" ${ }^{13}$ In order to make the plot more vivid right from the beginning of the novel, the narrator uses several rhetorical questions, to emphasize the idea that she is aware of everything and she knows all about the characters and the setting of the novel, all the details behind the scene, regarding each and every 'actor' from the book. With respect to the structure of the novel, it is built upon two main scenes. And by using the word 'scene' ('første billed', 'annet billede') instead of 'chapter', this can make the reader think about how the novel was initially projected as a drama: "Its dramatic possibilities were immediately apparent to the critics when it was published, and it was soon dramatised by Helge Krog, [...]. It was performed with great success in 1947 at Det norske teateret (The Norwegian Theatre - the major nynorsk company) in Oslo, and then in Sweden, Denmark and Finland. In 1951 it was made into

\footnotetext{
${ }^{12}$ Cora Sandel, Krane's Café: An Interior with Figures, translated by Elisabeth Rokkan (Athens and Ohio: Ohio University Press, 1968), 11.

${ }^{13}$ All the quotations from Kranes konditori: Interior med figurer (Krane's Café: An Interior with Figures) are taken from the English version of this novel translated in 1968 by Elisabeth Rokkan; (Sandel, tr. Rokkan 1968: 7).
} 
a popular film"14, directed by the Danish film director Astrid HenningJensen (1914-2002), followed by the theatrical representation from 2001, directed by Otto Homlung and Tine Thomassen for Riksteatret. ${ }^{15}$

One of the reasons this novel has clear features of a drama, also resides in the tendency of the writer to use more dialogues among the characters, a characteristic which makes the narrative alive, by listening to the characters' own voices and comments. In addition, "the heavy use of dialogue places much more responsibility on the reader to interpret and create meaning in the text". ${ }^{16}$ Therefore, the narrator is not always omniscient, being rather duplicated by 'an anonymous embedded narrator' ('anonym rammeforteller') as Sigurd Bretteville-Jensen explained in his article entitled "Beretterteknikken i Kranes konditori" ("The Narrative Technique in Krane's Café"), published in the Annual Journal of Norwegian Literature $(N L \AA)$. Another important aspect that makes the reader associate the structure of the novel with clear features of a dramatic text and to some extent even to a soap opera is the manner in which the plot is embroidered with various and sometimes intricate relationships among the characters. Professor Henning Howlid Wærp, in his article entitled "Konditoriet som livsbilde - Om Cora Sandels Kranes konditori" "The Café -A Portrayal of Life - About Cora Sandel's Krane's Café"), presents in a very clear manner, the connections among the characters of the novel. A closer examination of these relationships is of great importance because they are the backbone of the whole story. Since the plot of the novel does not present in such an obvious and accessible way these relations, the responsibility is subtly transferred to the understanding and the interpretation of the readers. For instance, Katinka Stordal has two children, a boy and girl, Jørgen and Borghild, and despite living alone, she did not yet get divorced from her husband, Peder Stordal. Together, they have a boy, Jørgen Stordal. Katinka had an affair with Justus Gjør, a magazine editor, and together they have a daughter, Borghild

\footnotetext{
${ }^{14}$ Garton 1993: 144.

${ }^{15}$ Henning Howlid Wærp, "Konditoriet som livsbilde - Om Cora Sandels Kranes konditori" ("The Café -A Portrayal of Life - About Cora Sandel's Krane's Café"), (Oslo: Unipub, 2005), 114.

${ }^{16}$ Ellen Rees, “Escape from the novel: Cora Sandel's Kranes konditori”, in Scandinavian Studies, vol. 72 , no. $2,2000,187$.
} 
Stordal. Meanwhile, Peder is in a relationship with Elise Øyen, a very 'precious lady' who works at a bank. She was previously married to Justus Gjør. Additionally, the pharmacist Lydersen had different affairs with Elise Øyen, Borghild Stordal, Larsen and Sønstegård.

In Krane's Café the representation of space can be analyzed and perceived from different narrative perspectives, with a special focus on the manner in which Cora Sandel presents the outside world from the inside, more precisely from the café. This device is not so often used in her writings, the urban space, with its streets and its special places, being usually used as a general setting. Consequently, there is an inner space, the café, where most of the events took place, and the outside world which is represented by short but meaningful depictions of the Arctic weather and how different it is from the rest of the world, together with short descriptions of the surrounding nature, far above the Arctic Circle: "At that moment the revolving door whirled violently, and in came Mrs Breien, red in face from wind and snow flurries, her hair tousled, her clothes soaked"17. The rapid change of the Arctic weather is a special feature in northern Norway: "The following day the weather was abominable; snow flurries ['snesklett'] and storm, as if it had never been spring" ${ }^{\prime 18}$. One can refer to these depictions as being 'literary specialties', in other words, ways of escaping from reality and that is why, from time to time, there are short remarks and brief descriptions of the season, which is about to come, about the coastal steamer (Hurtigruta), or different specific flowers, which announce the coming of a specific season of the year: "Fancy having green leaves on the table already, [...]. 'Soon be summer now, [...]. People have begun taking country walks. I've heard them say the snow's melted all the way to World's End. I know someone who's found a saxifrage too" ${ }^{\prime 19}$. It is an ingenious literary ability to combine brief depictions of the Arctic landscape with the tumultuous life of the inhabitants from this small coastal town, with a special focus on Katinka Stordal's existence. But despite the characters' needs and problems, the nature and the community life take their course: "It was early spring and the sun was

\footnotetext{
${ }_{17}$ Sandel, tr. Rokkan 1968: 100.

${ }^{18}$ Ibid. 90.

${ }^{19}$ Ibid. 59.
} 
shining. There were birch leaves and pussy willow on the tables. You could feel that summer was not far away"20. To a certain extent, the nature and the surrounding world are the ones that get people together: "At that moment a steamer hooted out on the fjord. Mrs Krane, Larsen and Sønstegård nodded at each other and rushed to the windows. For whatever is happening you must watch the coastal express come in, especially in fine weather, whitepainted and splendid, just like a foreign cruise ship"21 or as Miss Larsen acknowledged: "Soon it'll be summer, and people will be moving up to their cottages. Out on picnics day and night"22. For instance, in a conversation between Justus Gjør and Peder Stordal, they both forgot at that moment their misunderstandings and chose to enjoy and focus on the beauty of the surrounding nature: "Well, we've improved, haven't we, Justus? [...]. Nothing to complain about where the view is concerned. Wolf Mountain in the background; in the foreground the quay, with all sorts of activity. [...] I think is the view that appeals to me most"23.

Moving on to one of the most visited inner spaces in town, the café is presented as being the soul of the small town, the most important meeting point in town which besides offering its customers and guests a small bistro, it also spoils them with a great view of the whole town with its quay. For instance, on the one hand, the coastal steamer (Hurtigruta) has a great contribution both for the economic sustainability of the town and for increasing the urban tourism. On the other hand, this coastal steamer has also a psychological impact upon the life of the inhabitants. Since the plot was set in a coastal town, Hurtigruta might also confer, to a certain extent, a psychological comfort, by offering an essential amount of freedom and excitement to those who are bold in making changes in their lives.

The different spatial representations (i.e. the Arctic landscape, the café, the parlor, the quay) and the Arctic climate are the narration's key elements which animate the plot, the setting, and the characters' lives,

\footnotetext{
${ }^{20}$ Ibid. 13.

${ }^{21}$ Ibid. 41.

${ }^{22}$ Ibid. 16.

${ }^{23}$ Ibid. 76.
} 
turning it into a vivid novel, the reader's attention being gradually captured and refocused on the sequences of events.

Regarding the narrative technique, according to Sigur BrettevilleJensen, there are two narrative plans, one represented by 'the embedded narrator ('rammefortelleren') while the other one includes the three women from Krane's Café, Miss Krane, the owner of the café, together with the two slanderous waitresses, Miss Larsen and Miss Sønstegård. "The ideas of the three observant-figures' remarks" 24 and the shifting from the first to the second plan is marked by the change of tense, from past tense to present. ${ }^{25}$

The narrative voice is quite neutral even bitter and ironic while presenting and depicting the characters. In this respect, another important aspect is that the reader is not always aware whether there is the narrator or it is the inner reflection of one of the characters, since this is not clearly marked in the novel, not even through dashes or quotation marks. This type of narrator is rather an 'embedded narrator', a literary device which gives the whole novel a note of novelty, regarding its narrative structure. For instance, when introducing the figure of Elise Øysen, the description that follows is either the narrator's voice or Sønstegård's own thoughts, at a first sight being rather ambiguous: "She [Mrs Krane] forgot Sønstegård in watching Elise Øyen. What did that woman do to herself to keep that way? Nobody would know she was well on in her thirties, [...]. She probably had facials? At the hairdresser's? [...]. Elise Øysen looked the same age as the young wives. But nervous. Terribly restless" ${ }^{26}$. And the narrative voice continues even bitterly: "Mrs Krane had suddenly discovered what was new about Elise Øyen. It was the fox fur, the beautiful Arctic fox she was wearing around her neck. [...] 'The blue fox. The one from Berg and Fure's window. [...] Three hundred and fifty kroner!"”27, “[...] And yet - capricious as she is ..."28. The bitterness of the narrator is gradually outlined in making general assumptions, for instance when Sønstegård and Mrs Krane are described:

\footnotetext{
${ }^{24}$ My own translation, original text in Norwegian: "de tre observatørfigurenes tanker og iakttagelser" (Sigurd 1969: 87).

25 Sigurd 1969: 87.

${ }^{26}$ Sandel, tr. Rokkan 1968: 70.

${ }^{27}$ Ibid. 70, 71.

${ }^{28}$ Ibid. 77.
} 
"Sønstegård really was unbearable"29, or "Mrs Krane, [...], was incapable of explanations and incapable of controlling her feelings" ${ }^{\prime 3}$. Not even the protagonist, Katinka Stordal, is absolved from any irony of the narrative voice, being briefly described either by the bitter voice of the narrator or by one of the characters. For instance, there is a short and almost insignificant statement about Katinka, placed at the end of the description about Krane's Café: "Between the windows stands the big radiogram, which is danced to in the evenings and get foreign stations. Above that the mirror, the largest in town besides Mrs. Stordal's. But after all, she's a dressmaker" ${ }^{\prime 2}$. However, at a certain point, Mrs Krane acknowledged the following utterance, related to the fact that the new-formed couple in town, Katinka and Bowler Hat, will cause a real scandal in the community: "Dear God, Krane's in Southfjord, dear God, You know that, don't let there be any scandal while he's away. I'm not good at dealing with that kind of thing, it's not in me, You made me that way. Dear God, dear God..." 32 .

The special features of a small town consist not only in the several descriptions of the surroundings and in the sudden change of the Arctic weather, "here, where we have only two months of summer!"33, but also in the mentality of the inhabitants, the way in which they perceive the events and the manner they react upon them. Cora Sandel portrays each of them individually and most of the times indirectly, with a great literary and psychological artistry. She also pointed out the characters' weaknesses and their incapacity to adapt to change and to face the reality, without trying to amplify and even worse, to distort it through several, unimportant and useless gossips and rumors: "In a little place like this everyone knows each other"34. They cannot stop themselves from judging the others by the appearances. According to Henning Howlid Wærp: "The novel has two narrative plans, one is Katinka's story, the other is the café's story. [...] The novel directs the irony towards the community where the whole story was

\footnotetext{
${ }^{29}$ Ibid. 70.

${ }^{30}$ Ibid. 81.

${ }^{31}$ Ibid. 11.

${ }^{32}$ Ibid. 78.

${ }^{33}$ Ibid. 81.

34 Ibid. 61.
} 
'sketched', it is a social criticism where the personal needs or problems faced the flattest convention" ${ }^{\prime 3}$.

With reference to the interior of Krane's Café, it is divided into two parts, one including the bistro and the tables and the other one, the parlor or 'the back room' or 'privaten' in Norwegian: "In case there's anyone who hasn't heard, or who perhaps is quite unfamiliar with Krane's, we should first of all begin with the shop. They've made it attractive and spacious, with small tables dotted all over the room like the cafés down south" ${ }^{\prime 36}$. The parlor is the place where Katinka and Bowler Hat met each other. Their table is somewhere in the corner and from that moment on, the action has two main 'narrative stages', one being represented by the parlor, where the two protagonists shared their life experiences and their dreams, and the other one is the shop with its customers: "Now it's called 'the parlor'. The wallpaper is the brown one, patterned with large flowers that everyone remembers from his childhood. The console table with the mirror above it, the Krane's father once bought at an auction of Consul Klykken's belongings, stands as usual in one corner" ${ }^{\prime \prime}$. These two different worlds are separated by an imaginary curtain, represented by a sliding door which separates the two inner worlds in the café, while the revolving door, 'svingdøren' - the Norwegian equivalent of the word, separates the interior with figures from the outside world: "Fresh air around you on every side! [...] Anybody can have sunshine and fresh air, even the poor!"38. Regarding the inner space, John R. Stilgoe emphasizes in his foreword to the book The Poetics of Space, written by the French philosopher Gaston Bachelard (1884-1962), the idea that a 'house is a nest for dreaming, a shelter for imagining" 39 . He continues by stating that "Bachelard reveals time after time that setting is more than scene in works of art, that it is often the armature around which the work revolves.

\footnotetext{
${ }^{35}$ My own translation, original text in Norwegian: "romanen har to handlingsforløp, det ene er Katinkas historie, det andre er konditoriets historie. [...] Romanen retter ironien mot det miljø som fortellingen er lagt i munnen på, den er en kritikk av et samfunn der personlige behov eller problemer møtes av den flateste konvensjonalitet" (Wærp 2005: 115, 116).

${ }^{36}$ Sandel, tr. Rokkan 1968: 10, 11.

${ }^{37}$ Ibid.

${ }^{38}$ Ibid. 78.

${ }^{39}$ John R. Stilgoe, Foreword, in The Poetics of Space, ed. Gaston Bachelar, translated from French by Jolas Maria (Boston: Beacon Press, 1994), VIII.
} 
He elevates setting to its rightful place alongside character and plot, and offers readers a new angle of vision that reshapes any understanding of great painting and novels, and folktales too" ${ }^{\prime 0}$. In other words, the parlor is the place that "[...] shelters the day-dreaming, [...], protects the dreamer, [...] allows one to dream in peace. [...] is one of the greatest powers of integration for the thoughts, memories and dreams of mankind. [...] Past, present and future give the house different dynamism" ${ }^{41}$. Furthermore, 'the victim' of that inner world and the woman who dared to dream and share her thoughts with a total stranger, was Katinka Stordal: "So they were talking about Mrs Katinka. And there she was, sitting in the parlor - she and Bowler Hat. Talk about a situation! Of course the ladies did all they could, so as not to understand; but no one, [...], could scarcely help hearing snatches here and there" ${ }^{\prime 2}$. In other words, Katinka and Bowler Hat were sitting at a table in one of the corners of the parlor and Mrs Krane, Miss Larsen and Sønstengård, from the other side of the sliding door, were waiting to hear from the couple inside the parlor. According to Bachelard, the corners in a place represent the withdrawal into oneself, "the universe itself withdrawn into a corner with the daydreamer. [...] They will not hesitate to give this daydream all its reality"43. Both Katinka and Bowler Hat want to become themselves again, as they once were, without being all the time 'hunted' by the critical eye of the community and by the people around them.

It was the time of afternoon when many people looked in. If Mrs Krane had not cleared the parlor by this time, she was unlikely to manage it now unless its occupants were to leave of their own accord, in front of everybody. That would be a nice thing! [...]. If Katinka and Bowler Hat were to leave now, right under the noses of the others, anything might be said in town. Trafficking, they might say. [...] The door opened wide, shooting back into the wall with a thunderous clatter. Out came Katinka, Mrs Katinka, mother of two lovely children, as Mrs Breien so

\footnotetext{
${ }^{40}$ Ibid. X.

${ }^{41}$ Gaston Bachelar, The Poetics of Space, translated from French by Jolas Maria, foreword by John R. Stilgoe (Boston: Beacon Press, 1994), 6.

42 Sandel, tr. Rokkan 1968: 40.

${ }^{43}$ Bachelard 1994: 139.
} 
rightly said. And she simply walked past the assembled company as if she hadn't even seen them. After her came Bowler Hat, mockingly peering about him, chewing his cigarette and with his hat on his head. Katinka, on the other hand, was carrying hers. She left without looking round, her head held high, as if in triumphal procession. The last they heard of her was that unaccustomed, bell-like little laugh. The revolving door spun a couple of times. ${ }^{44}$

This unexpected scene, which for those who witnessed it, seemed to be taken from another story, coincides with the climax of the novel. Consequently, the narrator presents the ironical, dramatic and even comic reactions of those who were sitting on the other side of the parlor's sliding door, in the bistro: "Mrs Krane burst into tears, [...]. She snuffled and blew her nose, [...]. Stordal. He sat looking as if he had just dropped from the moon. [...] Lydersen gave a long-drawn-out whistle. [...] It was strange to watch Gjør too. [...] he was staring grimly, [...], he was rocking his foot backwards and forwards from heel to toe. He was not feeling kindly disposed" 45 .

Finally, the resolution of the novel consists in the fact that the bold female protagonist Katinka Stordal at least tried to make a radical change in her life, by getting out of her ordinary existence and of her daily routine, drinking wine in the middle of the day at the most popular café in town together with Bowler Hat. She was several times perceived as an unual woman in the sense that she wanted to be different from all the other ladies in town, a woman who, according to the others' mean observations, has no real and concrete principles in life, and who, above all was not seen as a real lady, but a simple and humble person who sewed dresses for the other women in town, being presented by Mrs Breien as 'a gifted dressmaker'. To put it differently, the other people in town seemed 'to pave' Katinka's way of living her own life, they seemed to know better what was right for her, seeing no other perspectives of improving her own life in the near future. According to the others' observations and evil comments, she was doomed to live in misery and to bury herself in work. In this respect, Cora Sandel

\footnotetext{
${ }^{44}$ Sandel, tr. Rokkan 1968: 79 - 80.

${ }^{45}$ Ibid. 80, 86.
} 
frequently focused on writing about disregarded women, who turned out to be powerful and gifted female protagonists. Their aim in life was to escape from their everyday life routine, by working hard to achieve their freedom and identity in succeeding in their artistic careers: "Throughout her fiction runs a sympathy with those who are marginalized by society, and an insistence on the absolute moral imperative of living authentically, which drives her female figures again and again to take a stance of opposition with a strength they did not know they had" 46 . However, even if Katinka Stordal is a strong and independent woman, she had only a glimpse of boldness when she forgot for a while about her problems and about the others and she dared to dream, especially when sitting at the table, in the corner of the parlor, because "we're created for warmth, [...]. We're created to be loved by someone. Imagine, I've discovered that. If we were not like that the world would stand still, we take so much on our shoulders [...]"47. Still, Katinka Stordal did not prioritize her feelings and her future projects, on the contrary, she rejected Bowler Hat and she chose to continue her simple living together with her children in the same coastal town in Norway.

\section{Final remarks}

Taking all these things into consideration, the novel Kranes konditori: Interior med figurer (Krane's Café: An Interior with Figures) is the place where the character Katinka Stordal was created. She is a female protagonist with great perspectives in life, but despite her miserable existence, she is marginalized by the community where she lives. In this respect, the Arctic landscape and the harsh weather conditions, to a certain extent, mirror her feelings and her inner struggle. Due to the exaggerated conservatism of the small coastal town's community, Katinka was the subject of discussions among the inhabitants of this northern town. Moreover, the sense of place in this novel is strongly related to its plot: "every story would be another story, and unrecognizable as art, it took up its characters and plot and happened somewhere else" ${ }^{\prime 4}$. Thus, the ingenuity of Cora Sandel resides in the fact that

\footnotetext{
${ }^{46}$ Garton 1993: 146.

${ }^{47}$ Sandel, tr. Rokkan 1968: 122.

${ }^{48}$ Welty 1977: 122.
} 
the setting of the novel is gradually revealed to the reader through short and yet full of importance depictions of nature and Arctic climate, throughout the novel. The beauty of the Arctic scenery counterbalances the simple living of Katinka, whose story ends on a note of hopelessness, but rather with the thought that sometimes in the future she will search again for her identity and self-fulfillment, at least through the achievements of her daughter Borghild. 


\section{References:}

\section{A. Books and articles}

Andersen, Per Thomas. Norsk litteraturhistorie (The History of Norwegian Literature). Oslo: Universitetsforlaget, 2012.

Bachelar, Gaston. The Poetics of Space. Translated from French by Jolas Maria. Foreword by John R. Stilgoe. Boston: Beacon Press, 1994.

Bretteville-Jensen, Sigurd. "Beretterteknikken i Kranes konditori" ("The Narrative Technique in Krane's Café"). In Norsk Litterær Årbok (Annual Journal of Norwegian Literature). Ed. Leif Mæhle. Oslo: Det Norske Samlaget, 1969.

Garton, Janet. Norwegian Women's Writing 1850-1990. London: The University Press, Cambridge, 1993.

Rees, Ellen. "Escape from the novel: Cora Sandel's Kranes konditori". In Scandinavian Studies, vol. 72, no. 2, 2000, pp. 181-198.

Sandel, Cora. Kranes konditori: Interior med figurer (Krane's Café: An Interior with Figures). Oslo: Gyldendal, 1946.

---. Krane's Café: An Interior with Figures. Translated by Elisabeth Rokkan. Athens and Ohio: Ohio University Press, 1968.

Sjoholm, Barbara. "Incognito Street". In The American Scholar, vol. 72, no. 3, 2003, pp. 65-76.

Welty, Eudora. "Place in Fiction". In The Eye of the Story. Selected Essays and Reviews. New York: Random House, 1977.

Wærp, Henning Howlid. 'Bilder av nord i Cora Sandels forfatterskap' ('Images of the North in Cora Sandel's Literary Work'). In Arktisk litteratur - fra Fridtjof Nansen til Anne B. Ragde (Arctic Literature - From Fridtjof Nansen to Anne B. Ragde). Stamsund: Orkana Akademisk, 2017, pp. 321-337.

---. "Konditoriet som livsbilde - Om Cora Sandels Kranes konditori" ("The Café -A Portrayal of Life - About Cora Sandel's Krane's Café"). Oslo: Unipub, 2005. 
106 | Revista Română de Studii Baltice şi Nordice / The Romanian Journal for Baltic and Nordic Studies 12 (2)

\section{B. Web postings:}

Wærp, Henning Howlid. 'Cora Sandel'. In Store norske leksikon. 2019, https://snl.no/Cora_Sandel, accessed at 10.09.2020. 